\title{
Pemberdayaan Kelompok Usaha Perempuan Desa Karangmekar Melalui Women Empowerment dan Social Media Marketing
}

\author{
Desta Sulaesih Mursyidah', Yuniati Fransisca², Albert Kurniawan Purnomo*3 \\ Fotuho Waruwu' ${ }^{4}$ Faisal Ikhram ${ }^{5}$ \\ 1,2,3,4,5Program Studi Manajemen, Fakultas Ekonomi, Universitas Nurtanio \\ *e-mail: albertsmart9@gmail.com ${ }^{3}$
}

\begin{abstract}
The people of West Java, especially the Cimahi city area, have tremendous culinary potential to be developed. With a population composition dominated by the productive age, human resource-based development to make Cimahi a creative industrial city is a strategic step that is possible to take so that it is expected to increase economic value for the community and the government. From the advantages of its potential, there are also weaknesses and challenges in facing a complex world, especially women's business groups, which need to be developed through women empowerment and online product marketing. The purpose of community service is to help develop and introduce superior products so that they are known to the wider community, one of which is through Instagram.
\end{abstract}

Keywords: Women Empowerment, Marketing, Online

\begin{abstract}
Abstrak
Masyarakat Jawa Barat khususnya kawasan kota Cimahi memiliki potensi kuliner yang luar biasa untuk dikembangkan. Dengan komposisi penduduk yang didominasi oleh usia produktif, pembangunan berbasis SDM untuk mewujudkan Cimahi sebagai kota industri kreatif menjadi langkah strategis yang sangat mungkin untuk dilakukan sehingga diharapkan bisa meningkatkan nilai ekonomi bagi masyarakat dan pemerintah. Dari kelebihan potensi yang dimiliki, ada juga kelemahan dan tantangan dalam menghadapi dunia kompleks, khususnya kelompok usaha perempuan, perlu dikembangkan melalui women empowerment dan pemasaran produk secara online. Tujuan dari pengabdian adalah membantu mengembangkan dan memperkenalkan produk unggulan agar dikenal masyarakat lebih luas salah satunya melalui Instagram.
\end{abstract}

Kata kunci: Women Empowerment, Pemasaran, Online

\section{PENDAHULUAN}

Usaha Mikro Kecil dan Menengah, sering disebut UMKM, memiliki pengaruh penting terhadap pertumbuhan ekonomi suatu negara (Oduntan, 2014; Widyani, et al., 2017). Permasalahan UMKM adalah kurang permodalan, kesulitan dalam pemasaran dan bahan baku, kurang terampil proses produksi, kurang dalam hal kemampuan manajerial dan keuangan, dan iklim usaha yang kurang kondusif. Maka dari itu ada salah satu solusi melalui strategi pemberdayaan masyarakat (Sunariani, et al., 2017). Pemberdayaan mengacu pada "kapasitas individu, kelompok dan / atau masyarakat untuk mengendalikan keadaan mereka, menggunakan kekuatan dan mencapai tujuan mereka sendiri, dan proses dimana, secara individu dan kolektif, mereka dapat membantu diri mereka sendiri dan orang lain untuk memaksimalkan kualitas hidup mereka (Digan, S.P., Sahi, G.K., Mantok, S., \& Patel,P.C, 2019). Pengusaha perempuan di negara berkembang menghadapi beberapa rintangan, mulai dari diskriminasi dan kendala sosial hingga pembatasan dalam membuat keputusan, bekerja, dan bepergian (Terjesen \& Elam 2012). Oleh karena itu, memahami kemampuan yang lebih besar untuk mengelola perusahaan sangat penting mengatasi hambatan yang dihadapi oleh pengusaha perempuan.

Dalam mengatasi rintangan-rintangan ini dalam upaya wirausaha mereka, perlu kendali atas kegiatan wirausaha, meningkatkan penentuan nasib sendiri untuk mengatasi rintangan, dan memiliki kepercayaan diri dalam melaksanakan kgiatan berbisnis dalam hal ini, UMKM. Chen, Sharma, Edinger, Shapiro dan Farh (2011) dalam Amalia dan Handoyo (2018) menyatakan bahwa beberapa penelitian sebelumnya menemukan bahwa pemberdayaan dapat digunakan untuk memprediksi kemunculan perilaku kerja inovatif. Perilaku kerja inovatif mencakup serangkaian 
kegiatan yang ditujukan untuk pengenalan, pengembangan, modifikasi, adopsi dan penerapan gagasan, dengan kata lain, perilaku kerja inovatif dapat dilihat sebagai penerapan kreativitas yang sukses dan sesuatu yang dapat memproduksi nilai tambah ekonomis (Amalia \& Handoyo, 2018). Selain itu Vecchio, et al. (2010) mengemukakan bahwa apabila wirausaha mampu menerapkan perilaku empowering yang bertujuan untuk mengembangkan self control, dan mendorong para anggota di dalamnya untuk melakukan sesuatu dengan inisiatif sendiri, maka mereka akan cenderung mengembangkan perilaku kreatif.

Munjuri dan K'Obonyo (2015) menguatkan dengan penelitian-penelitian Hales dan Klidas (1998) yang mendefinisikan pemberdayaan sebagai berbagi pengetahuan, informasi, dan kekuasaan dengan bawahan. Gagasan pemberdayaan melibatkan tenaga kerja yang diberikan tingkat fleksibilitas yang lebih besar dan lebih banyak kebebasan untuk membuat keputusan terkait pekerjaan. Ini sangat berbeda dengan teknik manajemen tradisional yang menekankan kontrol, hierarki dan kekakuan (Greasley, Bryman, Dainty, Price, Soetanto dan King, 2005).

Sementara itu, wirausaha termasuk UMKM, pada saat ini tidak terlepas dari bagaimana mempromosikan produk dan jasa secara daring (online). Pada umumnya, masyarakat saat ini cenderung tidak terlepas dari ponsel atau gadget dimana hal tersebut menjadi kebutuhan pokok sehari-hari mereka. Dunia online telah sangat banyak memengaruhi kehidupan masyarakat sehari-hari yang terkadang bahkan tampak mustahil untuk membayangkan hidup tanpa teknologi dan komunikasi (eMarketing Institute, 2018: 11). Fenomena ini secara alami ditransfer ke dunia usaha, di mana teknologi baru membukakan dan menarik banyak peluang. Peluang tersebut diambil oleh para pelaku usaha untuk dapat mempromosikan produk dan jasanya melalui pemanfaatan media secara online. Anggapan untuk memanfaatkan media online tidak asing lagi di telinga para pelaku usaha, apalagi media online memberikan efektifitas penyampaian lebih cepat kepada masyarakat. Disamping itu, pelaku usaha juga tidak lepas dari pemanfaatan digital marketing sebagai salah satu program promosi-nya, sekaligus sebagai tantangan pelaku usaha untuk memperkenalkan produk dan jasanya kepada masyarakat.

Selain women empowerment, kegiatan ini bertujuan untuk memberdayakan para pelaku usaha dalam menjawab tantangan tersebut. Kegiatan ini akan diimplementasikan khususnya kepada kelompok usaha perempuan strategi media sosial pada pemasaran produk-nya. Melihat fakta yang ada pada kelompok usaha perempuan di Desa Karangmekar Kecamatan Cimahi Tengah adalah sebetulnya banyak potensi produk makanan dan kerajinan tangan yang dapat dijual ke luar daerah, namun hal tersebut tidak dapat terlaksana dikarenakan keterbatasan kelompok usaha dalam memanfaatkan internet access dan dunia digital untuk menunjang usahanya.

Berikut beberapa produk yang dihasilkan kelompok usaha perempuan :

Tabel 1. Jenis Usaha, Produk, dan Harga Hasil Usaha Kelompok Usaha Perempuan Desa Karangmekar

\begin{tabular}{llll}
\hline No & Jenis Usaha & Nama Produk & Harga (dalam Rp) \\
\hline 1 & Minuman kemasan & Cadbury Hot Chocolate Drink & 68.000 \\
2 & Makanan & Seafood Asam Manis & 10.000 \\
3 & Makanan & Lontong Kari & 5.000 \\
4 & Makanan & Lumpia Basah & 7.000 \\
5 & Fashion & Gamis Babydoll Wolfis & 150.000 \\
6 & Makanan & Kue Basah & $1.000-1.500$ \\
7 & Makanan & Tahu Crispy Pedas & 5.000 \\
8 & Makanan & Kue Tart dan Cookies & Sesuai pesanan \\
9 & Fashion & Men's Sweater & 45.000 \\
10 & Makanan & Mie Kocok & 10.000 \\
11 & Makanan & Tumpeng Besar dan Tumpeng Mini (Tumini) & Sesuai pesanan \\
12 & Makanan & Ayam Geprek & 10.000 \\
11 & Makanan & Nasi Gudeg Krecek + Telur Pindang & 12.000 \\
12 & Makanan & Kulit Lumpia (Kulpi) & 8.000 \\
13 & Makanan & Pangsit Rasa (Paras) & 5.000 \\
14 & Makanan & Gule Tutut Hot & 10.000 \\
\hline
\end{tabular}


Manfaat kegiatan ini adalah sebagai berikut. (1) Bagi pemerintah, sebaai masukan program pemberdayaan masyarakat yang berbasis kearifan lokal suatu daerah. (2) Bagi instansi suatu daerah, menjadi program unggulan dalam memberdayakan perempuan suatu daerah dan program pengolahan hasil usaha para perempuan ibu rumah tangga yang dapat meningkatkan nilai jualnya. (3) Bagi masyarakat, menjadi sarana masyarakat, khususnya warga perempuan untuk mengembangkan potensinya dan meningkatkan kesejahteraan warga suatu daerah (4) menjadi salah satu model pelatihan pemberdayaan perempuan yang berkelanjutan dalam rangka kemandirian warga perempuan. Berdasarkan paparan yang telah dikemukakan sebelumnya, maka fokus kegiatan ini yaitu memberdayakan kelompok usaha perempuan di Desa Karangmekar Kecamatan Cimahi Tengah melalui pemanfaatan women empowerment dan pemasaran produk melalui digital marketing media sosial.

\section{METODE}

Kegiatan PKM ini berlokasi di Kelurahan Karangmekar Kecamatan Cimahi Tengah, dengan sasaran peserta yang lebih spesifik yaitu para wanita di RW 04 Kelurahan Karangmekar Kecamatan Cimahi Tengah yang memiliki usaha. Di lokasi tersebut terdapat berbagai jenis usaha yang mayoritas memiliki usaha makanan dan fashion. Kegiatan PKM ini melibatkan 1 (satu) narasumber eksternal dan 25 (dua puluh lima) orang peserta dari RW 04 Kelurahan Karangmekar Kecamatan Cimahi Tengah yang memiliki usaha.

Adapun kegiatan PKM ini memiliki beberapa tahap pelaksanaan, yakni, Tahap Survei, Tahap Tahap Pelaksanaan Program, dan Tahap Penyusunan Laporan Kegiatan Akhir, yang dapat dipaparkan secara lebih lengkap sebagai berikut:

\section{Tahap Survei}

a. Survei pertama dilaksanakan pada Jumat, 11 Oktober 2019 yaitu wawancara pendahuluan dengan ketua PKK Kelurahan Karangmekar Cimahi Tengah (Ibu Farida). Survei pertama bertempat di rumah salah satu informan kami yang berlokasi di Jalan Lurah Kelurahan Karangmekar Kecamatan Cimahi Tengah. Pada saat tersebut tim kami memutuskan untuk mengambil peserta dari RW 04 saja dikarenakan keterbatasan waktu dan perizinan. Didapatkan dari hasil wawancara yakni dari seluruh perempuan yang ada di RW 04 Kelurahan Karangmekar Cimahi, terdapat kurang lebih 20 - 25 perempuan yang memiliki usaha, dimana mayoritasnya memiliki usaha makanan dan fashion. Seluruh penjualan produk tersebut masih bersifat tradisional, dalam arti belum mengaplikasikan media sosial untuk promosinya. Adapun jenis produk yang dijual adalah dari RT 01/ RW 04: sosis goreng, cireng isi, dan warung sembako; RT 02/ RW 04: mie ayam, mie kocok, warung sembako, dan baju; RT 03/ RW 04: cemilan kulit lumpia (kulpi) dan warung; RT 04/ RW 04: bakso tahu, bubur ayam, dan baju muslim; RT 05/ RW 04: kue basah dan kedai jus; serta RT 06/ RW 04: kue basah, kue kering, dan gorengan. Dokumen dapat disajikan pada beberapa gambar berikut:

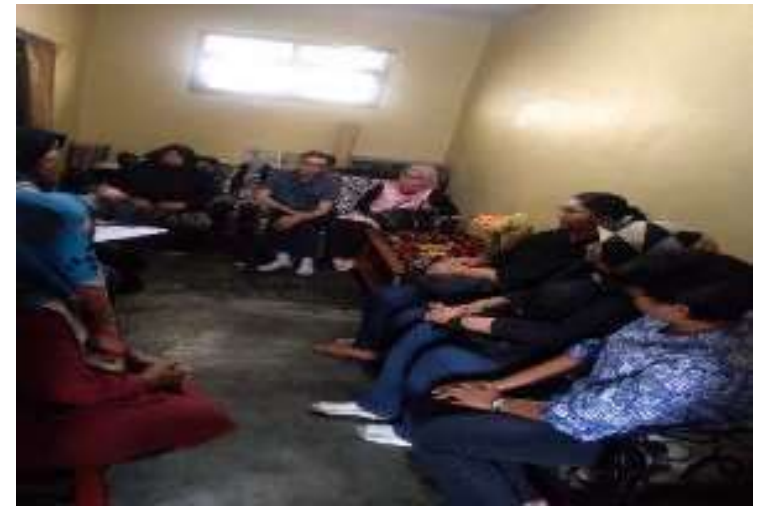

Gambar 1. Wawancara Dengan Ketua PKK Kelurahan Karangmekar 
b. Peninjauan lokasi untuk kegiatan PKM pertama dilaksanakan pada Jumat, 1 November 2019. Peninjauan lokasi ini bertempat di rumah Bapak Asep sebagai Ketua RW 04 Kelurahan Karangmekar Kecamatan Cimahi Tengah. Berdasarkan hasil peninjauan lokasi tersebut, kelompok kami direkomendasikan untuk melaksanakan kegiatan untuk Senin 4 November 2019 di Masjid Tajuddin Jl. H. Tajuddin Kelurahan Karangmekar Kecamatan Cimahi Tengah. Dokumen disajikan sebagai berikut:

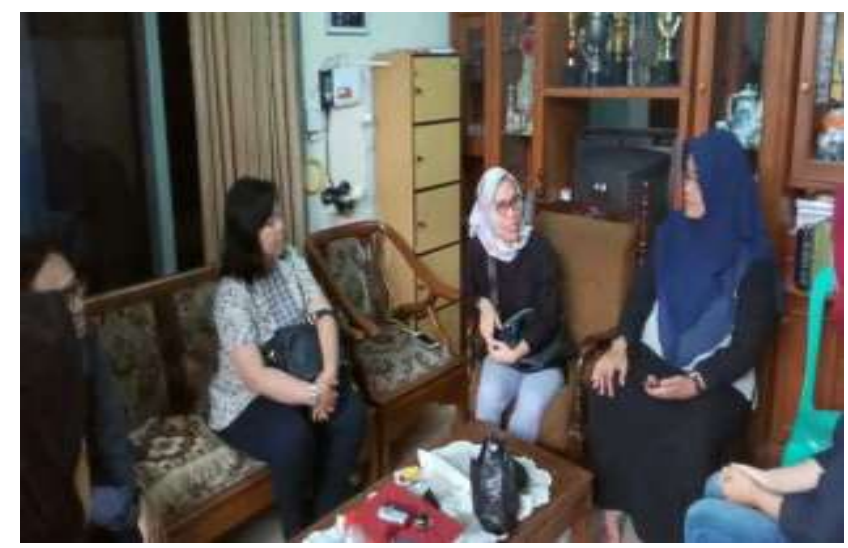

Gambar 2. Peninjauan Lokasi dan Diskusi Mengenai Tempat Untuk Kegiatan PKM Pertama Bersama Ketua PKK Kelurahan Karangmekar

2. Tahap Pelaksanaan Program

a. Kegiatan PKM Pertama

Kegiatan pertama dari Pkm ini dilaksanakan pada Senin, 4 November 2019. Kegiatan ini dilaksanakan untuk memberikan pemaparan materi mengenai women empowerment dan social media marketing yang dipaparkan oleh narasumber dengan masing-masing bidang peminatan. Pemaparan mengenai women empowerment disampaikan oleh narasumber dengan bidang peminatan manajemen sumber daya manusia (MSDM) dan social media marketing disampaikan oleh narasumber dengan bidang peminatan manajemen pemasaran. Susunan acara dijelaskan sebagai berikut:

Tabel 2. Susunan Acara Senin 4 November 2019

\begin{tabular}{|c|c|c|c|c|}
\hline Waktu & Deskripsi & Narasumber & Judul Materi & Peminatan \\
\hline $\begin{array}{l}08.00- \\
08.22\end{array}$ & $\begin{array}{l}\text { Registrasi narasumber } \\
\text { dan peserta }\end{array}$ & - & - & - \\
\hline $\begin{array}{l}08.22- \\
08.25\end{array}$ & $\begin{array}{l}\text { Doa Pembuka oleh Bapak } \\
\text { Faisal Ikhram, S.E.M.M. }\end{array}$ & - & - & - \\
\hline $\begin{array}{c}08.25- \\
08.30 \\
\end{array}$ & $\begin{array}{c}\text { Sambutan Ketua } \\
\text { Pelaksana Pkm }\end{array}$ & - & - & - \\
\hline $\begin{array}{l}08.30- \\
08.45\end{array}$ & & $\begin{array}{l}\text { Bapak Albert } \\
\text { Kurniawan Purnomo, } \\
\text { S.E.M.M. }\end{array}$ & $\begin{array}{c}\text { Women } \\
\text { Empowerment }\end{array}$ & MSDM \\
\hline $\begin{array}{l}08.45- \\
09.00\end{array}$ & Pemaparan Materi & $\begin{array}{c}\text { Bapak Fotuho Waruwu, } \\
\text { S.E.M,M, }\end{array}$ & $\begin{array}{c}\text { Women } \\
\text { Empowerment - } \\
\text { Motivasi } \\
\text { Berwirausaha }\end{array}$ & MSDM \\
\hline $\begin{array}{l}09.00- \\
09.15\end{array}$ & & $\begin{array}{c}\text { Bapak Faisal Ikhram, } \\
\text { S.E.,M.M. }\end{array}$ & $\begin{array}{c}\text { Women } \\
\text { Empowerment - } \\
\text { Perlunya Perempuan } \\
\text { Berkoperasi }\end{array}$ & MSDM \\
\hline
\end{tabular}


09.15-

09.30

09.30-

10.00

$10.00-$

10.30

$10.30-$

10.33

10.33-

11.00
Ibu Yuniati Fransisca, S.E.,M.M.

Ibu Desta Sulaesih Mursyidah, S.E.,M.M.

Bapak Firly Firmansyah, S.E.M.M.
Digital Marketing

Bahasa Promosi

Yang Efektif Melalui Pemasaran Media Sosial

Pentingnya Digital

Marketing untuk

Branding dan

Pembagian Hasil

Keuntungan dari

Penjualan di

Instagram

Pemasaran

Pemasaran
Doa Penutup oleh Bapak

Faisal Ikhram, S.E.M.M.

Penutup berikut:

Dokumen yang diambil dalam bentuk foto pada kegiatan pertama akan disajikan sebagai

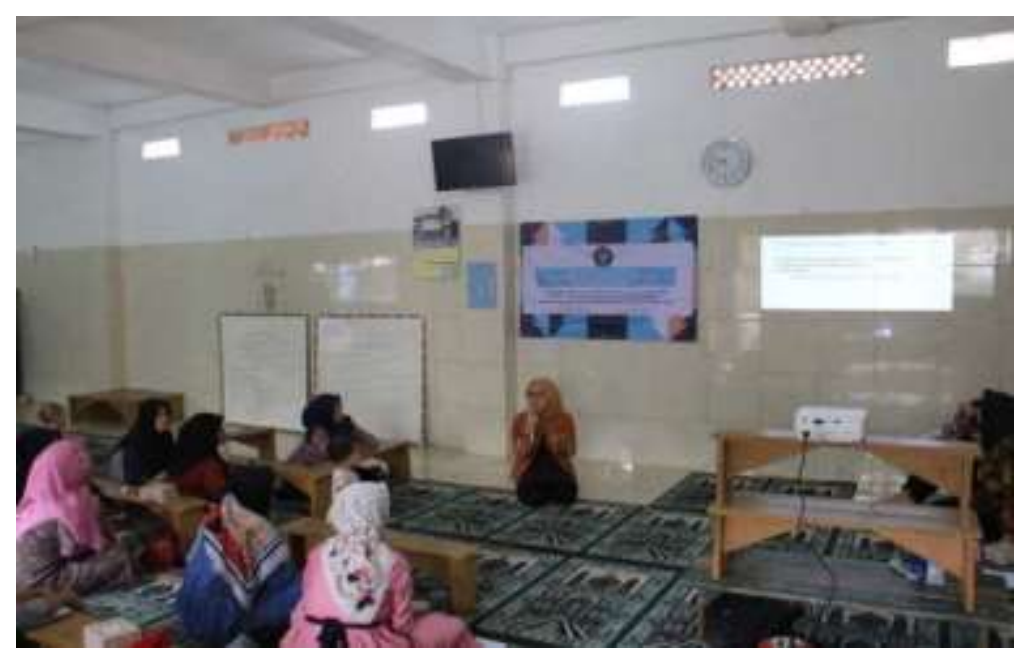

Gambar 3. Pemaparan oleh Ibu Desta Sulaesih Mursyidah, S.E.,M.M.

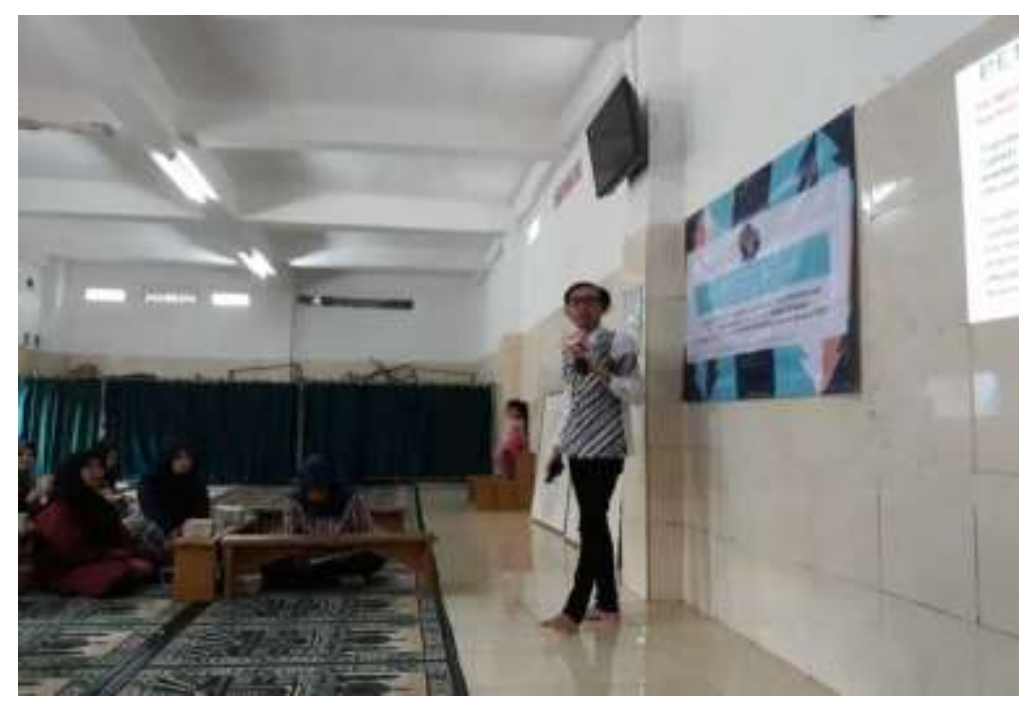

Gambar 4. Pemaparan oleh Bapak Albert Kurniawan Purnomo, S.E.,M.M. 


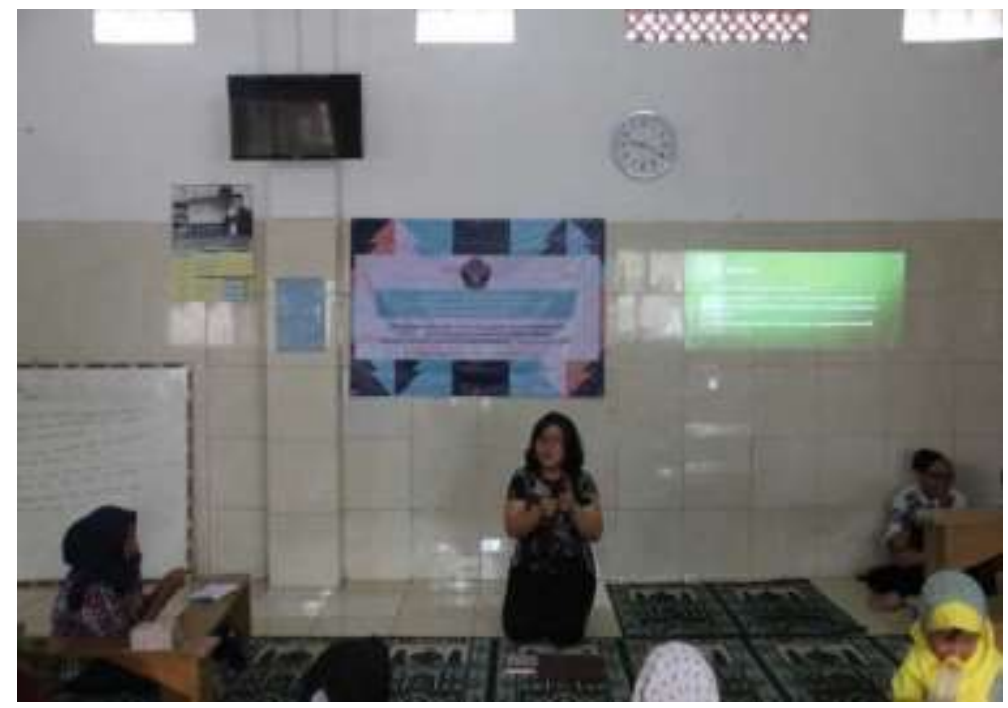

Gambar 5. Pemaparan oleh Ibu Yuniati Fransisca, S.E. M.M.

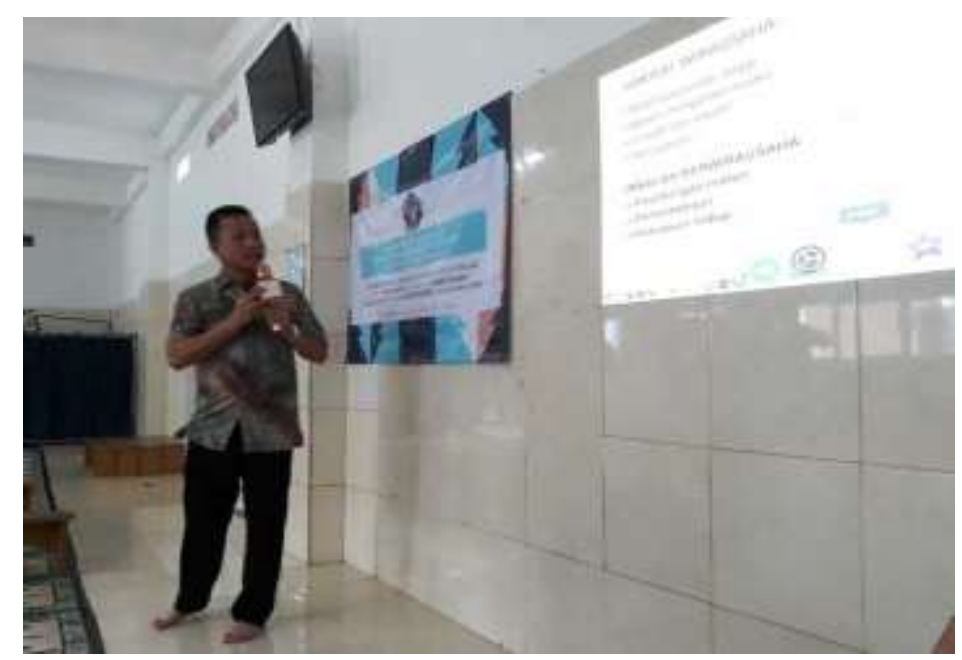

Gambar 6. Pemaparan oleh Bapak Fotuho Waruwu, S.E.,M.M.

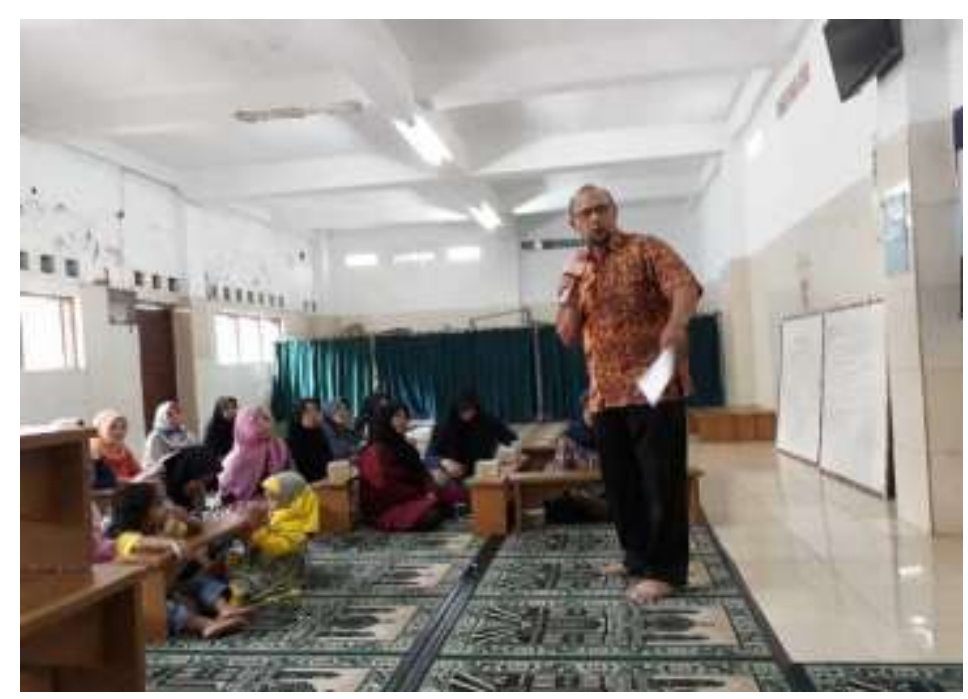

Gambar 7. Pemaparan oleh Bapak Faisal Ikhram, S.E.,M.M. 


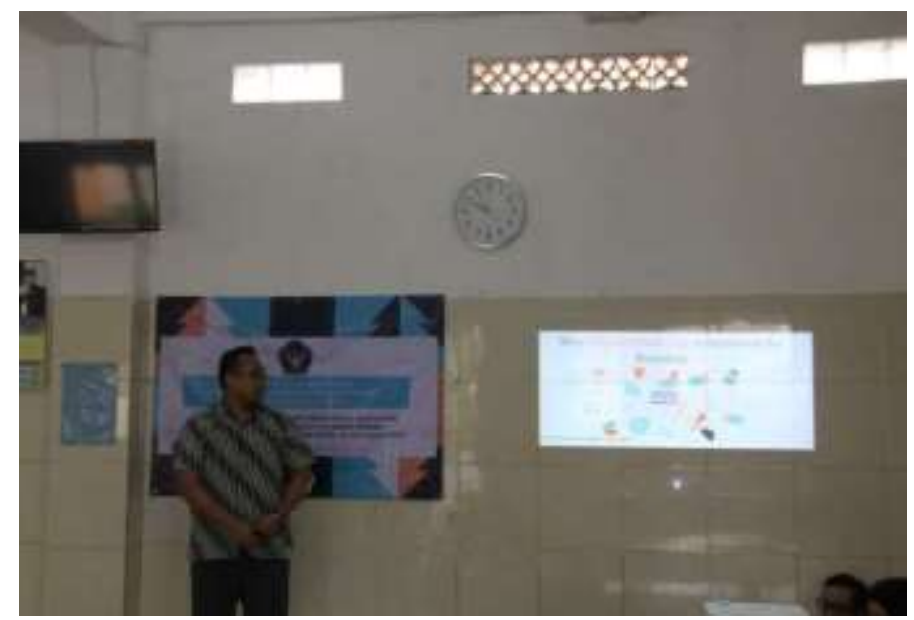

Gambar 8. Pemaparan oleh Bapak Firly Firmansyah, S.E.,M.M.

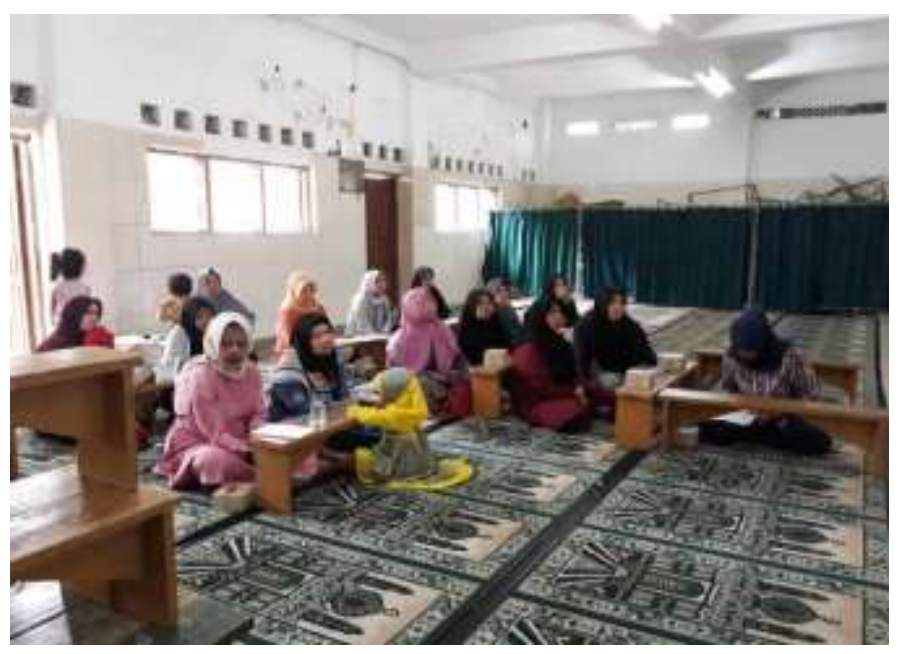

Gambar 9. Foto Ibu Ibu Peserta PKM

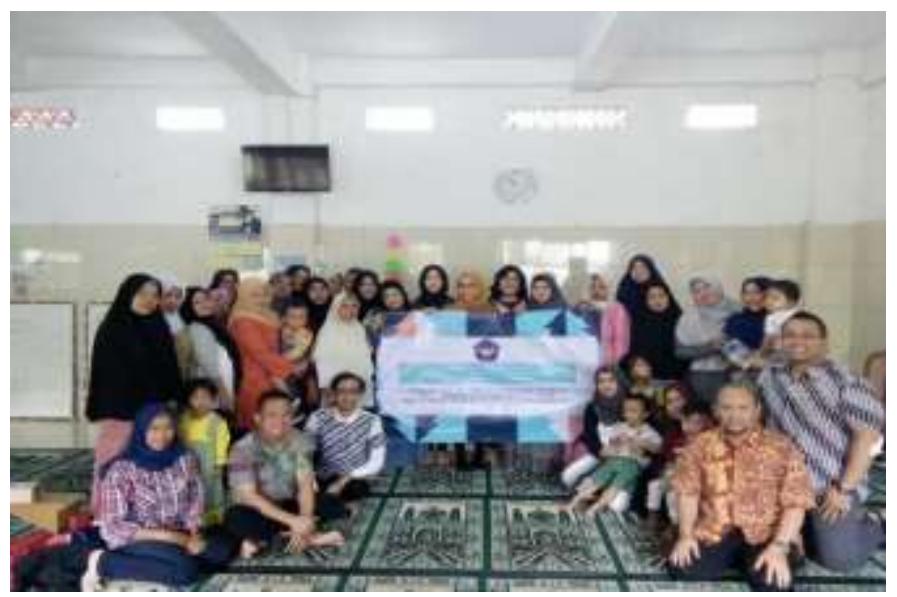

Gambar 10. Foto Bersama

b. Kegiatan PKM Kedua

Kegiatan kedua dari PKM ini dilaksanakan pada Senin, 20 Januari 2020 yang dilaksanakan di TK Bunga Mulia Kelurahan Karangmekar Kecamatan Cimahi Tengah yang dilaksanakan pukul 12.00 - 14.00 WIB. 


\section{HASIL DAN PEMBAHASAN}

Salah satu bagian dalam kegiatan pertama PKM ini adalah memberikan sosialisasi mengenai teknik mengambil foto dengan media kamera digital dan kamera ponsel, sudut pengambilan foto dan pengambilan cahaya pada saat foto. Di akhir kegiatan pertama PKM ini, diumumkan kepada para peserta untuk dapat mengunggah foto produknya masing-masing di instagram HAYU_JAJAN.

Berikut adalah Instagram hasil dari kontribusi kelompok bagi kelompok usaha perempuan Desa Karangmekar:
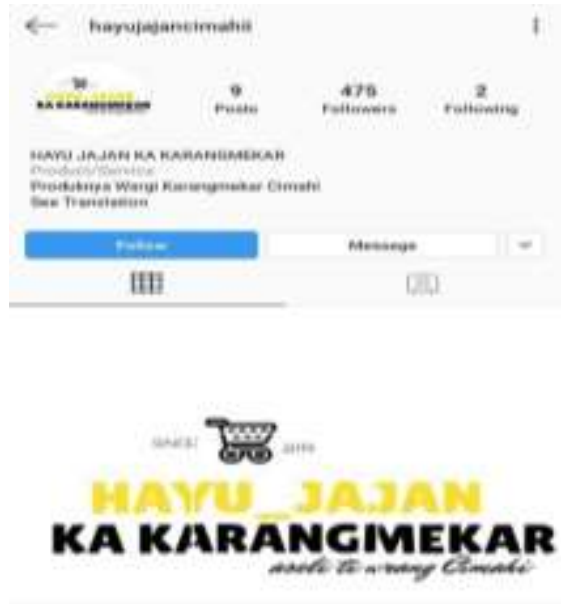

(n) $\quad$ a $\oplus \quad \circ \quad 2$

Gambar 11. Media Sosial Instagram

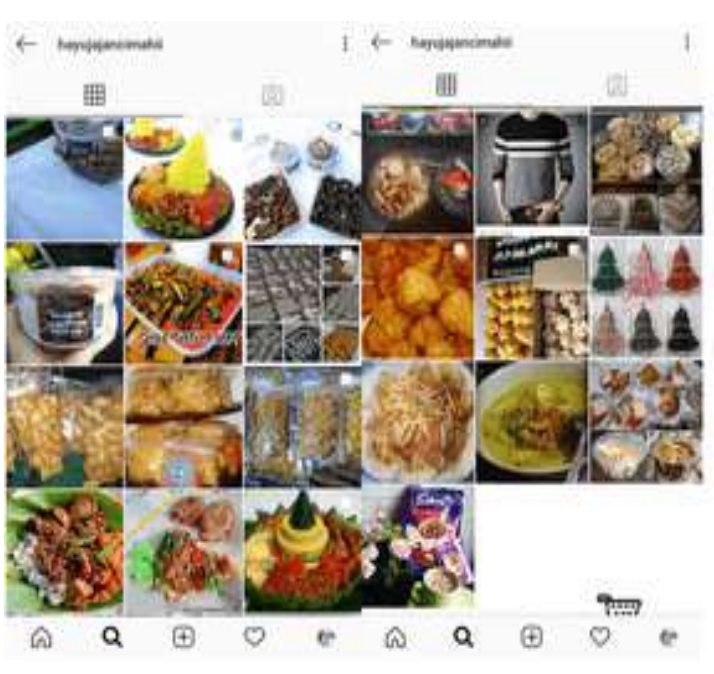

Gambar 12. Feed Instagram HAYU_JAJAN yang Dibuat Oleh Tim PKM

Foto produk usaha peserta yang telah diunggah kemudian akan dipilih oleh kelompok pada kegiatan PKM kedua. Foto produk yang telah dipilih oleh kelompok adalah Tumpeng mini (Tumini), Seafood Asam Manis, dan Gule Tutut Hot. Berikut adalah feed instagram HAYU_JAJAN berisi foto-foto produk usaha yang telah diunggah oleh para peserta dan gambar ketiga foto produk usaha yang telah dipilih oleh kelompok:

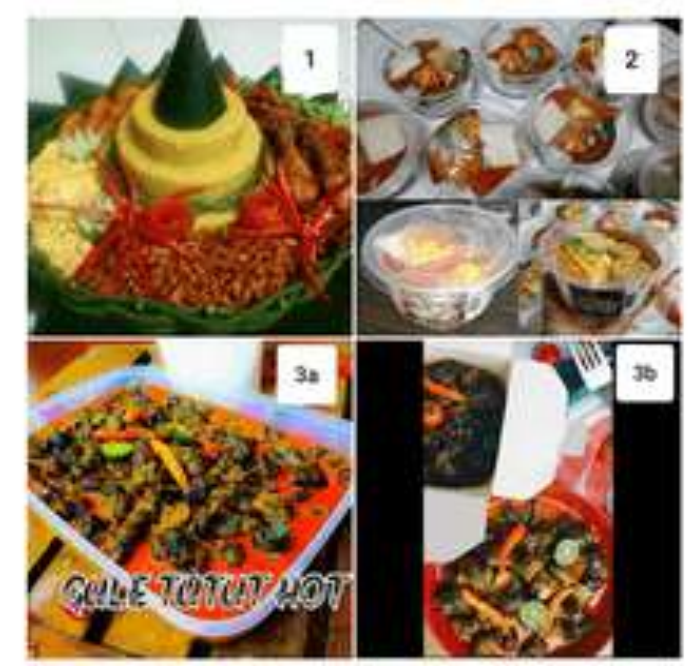

Gambar 13. Ketiga Produk Yang Terpilih

(1) Tumpeng mini, (2) Seafood asam manis, (3a dan 3b) Gule tutut hot 
Adapun tujuan kegiatan PKM kedua tanggal 20 Januari 2020 adalah memberikan pelatihan kepada 3 (tiga) orang peserta dimana produknya telah dipilih dan dinyatakan menang oleh kelompok. Pemenang foto yang terpilih mendapat hadiah berupa pelatihan pengambilan foto produk serta pemberian kesempatan foto produknya untuk diunggah di feed instagram paling atas dan kesempatan produknya dipromosikan oleh kelompok. Hal ini dapat menjadi dukungan untuk para ibu berkreasi, berinovasi, dan berwirausaha.
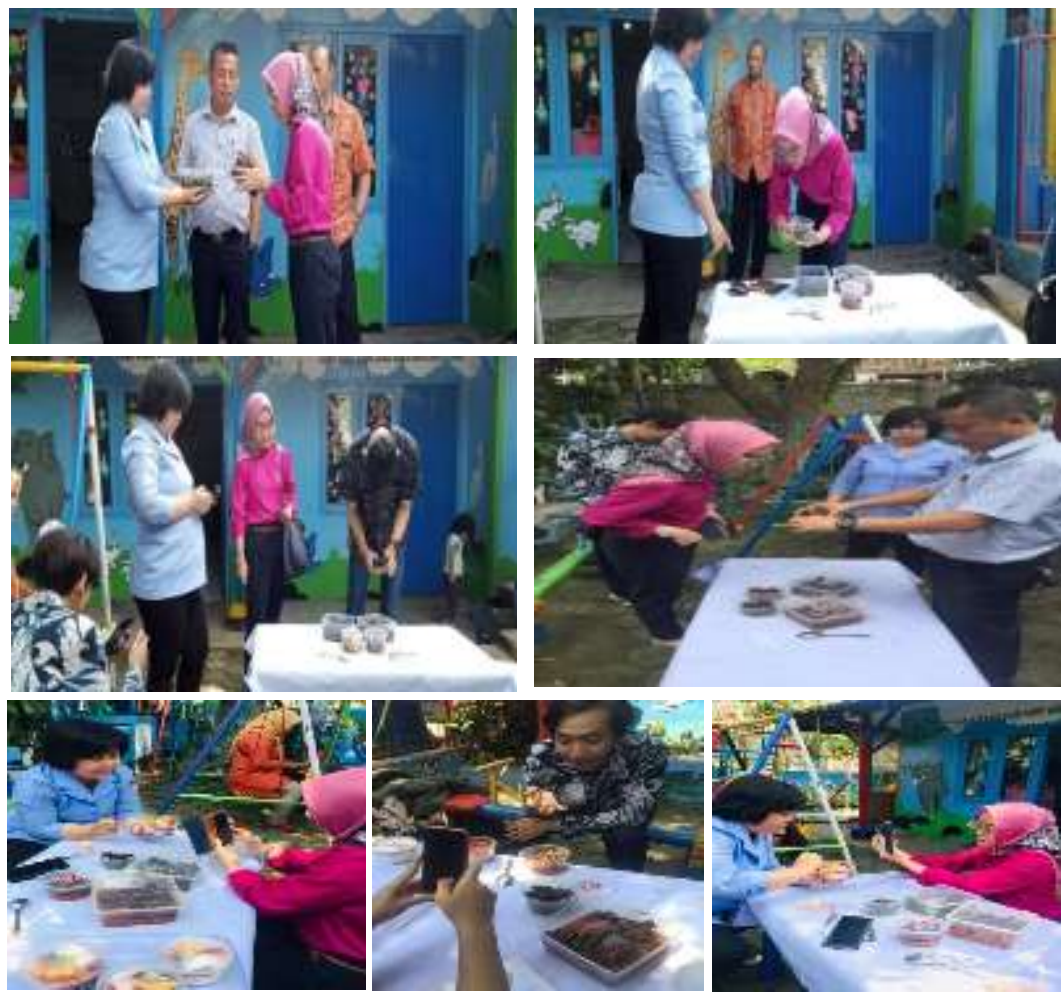

Gambar 14. Kegiatan PKM Ke-2 Di TK Bunga Mulia Kel. Karangmekar Kec. Cimahi Tengah

Tahap terakhir dari kegiatan Pengabdian adalah pelaporan. Semua kegiatan telah dilaporkan, adapun bentuk laporan berupa artikel, spanduk kegiatan.

\section{KESIMPULAN}

Kesimpulan harus mengindikasi secara jelas hasil-hasil yang diperoleh, kelebihan: Beberapa peserta menjadi terbuka wawasan tentang peluang usaha dan mampu berinovasi. Selain itu, para perempuan mulai berani memulai menawarkan produk melalui media sosial, dan menerima pesanan. Dari semua potensi tersebut, masih ada juga kekurangan yang tim kami temukan diantaranya adalah produk terpilih merupakan produk yang tidak tahan lama, hanya bertahan satu hari atau beberapa hari saja, hasil packaging / kemasan produk makanan yang kurang menarik, Pemikiran para peserta yang masih ingin berjualan secara offline, konvensional / tradisional dengan anggapan hanya mencari tambahan uang atau mengisi kesibukan dan Membuat produk hanya atas dasar pesanan (order) saja, dan ada kalanya respon kurang cepat ketika ada pesanan dari Instagram HAYU_JAJAN

Ada beberapa kendala atau kekurangan teknis pada saat tim melakukan pengabdian di lapangan diantaranya adalah keterbatasan kendala tempat saat akan melakukan sosialisasi, kendala komunikasi (kurang resonsif).

Kemungkinan pengembangan yang tim kelompok kami telah persiapkan ke tahap selanjutnya adalah : Membantu membuatkan Izin Usaha Mikro (IUM), Memberikan pelatihan dan 
praktik membuat packaging (kemasan) produk yang lebih menarik dan memiliki nilai jual tinggi ketika dijual secara konvensional maupun online, dan Sosialisasi strategi memertahankan bisnis di masa krisis seperti saat pandemi Covid-19.

\section{DAFTAR PUSTAKA}

Amalia, D.T., \& Handoyo, S. (2018). Peran Psychological Empowerment dalam Hubungan antara Empowering Leadership dengan Perilaku Kerja Inovatif. Jurnal Psikologi Teori dan Terapan 2018, Vol. 9, No. 77-90 p-ISSN: 2087-1708; e-ISSN: 2597-9035.

Digan, S.P., Sahi, G.K., Mantok, S., \& Patel,P.C. (2019). Women's Perceived Empowerment in Entrepreneurial Efforts: The Role of Bricolage and Psychological Capital. Journal of Small Business Management, 57(1), pp. 206-229.

eMarketing. (2018). Social Media Marketing. Copenhagen: eMarketing Institute

Kotler, P., Armstrong, G., Ang, S. H., Tan, S. T., Yau, O. H. M., \& Leong, S. M. (2017). Principles of Marketing: An Asian Perspective (4th Edition). Harlow : Pearson Education

Munjuri, M.G. , \& K'Obonyo, P. (2015). Human Capital, Employee Empowerment and Performance of Commercial Banks and Insurance Firms in Kenya. International Journal of Arts and Commerce Vol. 4 No. 6, August, 2015.

Oduntan, K. O. (2014). The role of small and medium enterprises in economic development: The Nigerian experience. International Conference Art Economic and Management, 75-80.

Sharma, P., and S. K. Varma. (2008). "Women Empowerment through Entrepreneurial Activities of Self Help Groups." Indian Research Journal of Extension Education 8(1), 46-51.

Sunariani, N.N., Suryadinatha, AAN.O., \& Mahaputra, I. IDM.R. (2017). Pemberdayaan Usaha Mikro, Kecil, dan Menengah (UMKM) Melalui Program Binaan di Provinsi Bali. Jurnal Ilmiah Manajemen dan Bisnis Volume 2 No 1 Tahun 2017. ISSN : 2528-1208

Terjesen, S., and A. Elam. (2012). "Women Entrepreneurship: A Force for Growth." International Trade Forum. 2, 16-18.

Vecchio, R.P., Justin, J.E., \& Pearce, C.L. (2010). Empowering leadership: An examination of mediating mechanisms within a hierarchical structure. The Leadership Quarterly, 21 (3), 530542. DOI: 10.1016/j.leaqua.2010.03.014.

Widyani, A.A.D., Sarmawa, I,W.G., \& Dewi, I.G.A.M. (2017). The Roles of Knowledge Sharing in Mediating the effect of Self Efficacy and Self Leadership Toward Innovative Behavior. JMK, Vol. 19, No.2, September 2017, 112-117 DOI: 10.9744/jmk.19.2.112-117 ISSN 1411-1438 print / ISSN 2338-8234 online. 